\title{
Tooth Loss and Perceived Masticatory Ability in Post-Menopausal Women
}

\author{
Bunga Riadiani ${ }^{1}$, Ratna Sari Dewi², Nina Ariani², Farisza Gita² \\ ${ }^{1}$ Undergraduate Program, Faculty of Dentistry, Universitas Indonesia, Jakarta 10430, Indonesia \\ ${ }^{2}$ Department of Prosthodontics, Faculty of Dentistry Universitas Indonesia, Jakarta 10430, Indonesia \\ Correspondence e-mail to: bunga.riadiani@yahoo.com
}

\begin{abstract}
Post-menopausal women experience physiological hormonal changes that reduce bone density which leads to tooth loss and presumably affect masticatory function. Objective: This study aims to determine association between tooth loss and masticatory ability in post-menopausal women. Methods: Cross sectional study of 95 post-menopausal women at Posbindu Lansia Pergeri Depok, West Java was performed. Subjects answered questionnaires and intra oral examination was performed. Chi square analysis was conducted to relate age, menopausal period, education level, tooth loss and denture use with masticatory ability. Results: $47 \%$ subjects lost $>10$ teeth, $27 \%$ subjects lost 6-10 teeth and 26\% subjects lost $<6$ teeth. Seventy-six percent of subjects did not wear dentures. Menopausal period, tooth loss, and age had significant correlation with masticatory ability $(p<0.05)$. Conclusions: This study concludes that masticatory ability in post-menopausal women is significantly affected by length of menopausal period, tooth loss and age $(p<0.05)$.
\end{abstract}

\begin{abstract}
ABSTRAK
Kehilangan gigi dan kemampuan mastikasi subjektif pada perempuan pasca menopause. Perempuan menopause mengalami perubahan hormon yang dapat mengakibatkan penurunan densitas tulang yang mempengaruhi hilangnya gigi, sehingga berpengaruh terhadap fungsi mastikasi. Tujuan: Penelitian ini bertujuan untuk menganalisis hubungan kehilangan gigi dengan kemampuan mastikasi perempuan pasca menopause secara subjektif. Metode: Penelitian potong lintang dengan subjek 95 perempuan pasca menopause di Posbindu Lansia Pergeri Depok, Jawa Barat. Subjek menjawab kuesioner dan dilakukan pemeriksaan intra oral. Analisis Chi Square digunakan untuk menghubungkan usia, lama menopause, tingkat pendidikan, kehilangan gigi dan pemakaian gigi tiruan dengan kemampuan mastikasi. Hasil: Hasil penelitian menunjukkan sebanyak $47 \%$ subjek mengalami kehilangan $>10$ gigi, $27 \%$ subjek kehilangan $6-10$ gigi dan $26 \%$ subjek kehilangan $<6$ gigi. $76 \%$ subjek tidak memakai gigi tiruan. Kemampuan mastikasi memiliki hubungan bermakna dengan kehilangan gigi, lama menopause dan usia $(p<0,05)$. Simpulan: Dapat disimpulkan, jumlah gigi hilang, lama menopause, dan usia mempengaruhi kemampuan mastikasi perempuan pasca menopause secara signifikan $(p<0,05)$.
\end{abstract}

Key words: masticatory ability; post-menopause; questionnaire; tooth loss; women

\section{PENDAHULUAN}

Berdasarkan data statistik, jumlah penduduk Indonesia akan berkembang terus sehingga estimasi jumlah perempuan menopause mencapai 30,3 juta jiwa ${ }^{1}$, sementara hasil Riskesdas 2007 menyatakan bahwa kondisi tak bergigi terdapat pada usia 65 tahun sebesar $17,6 \%{ }^{2}$

Proses menua adalah suatu proses fisiologis kemunduran semua fungsi tubuh dan perubahan fisik yang dapat mempengaruhi kesehatan gigi dan mulut sehingga pengobatan yang harus dilakukan menjadi lebih rumit. ${ }^{3,4}$ Gangguan pada rongga mulut yang dialami lanjut usia seperti kehilangan gigi dapat diakibatkan jarangnya dilakukan pemeriksaan kesehatan gigi dan mulut. ${ }^{5}$ Hal ini antara lain berhubungan dengan tingkat pendidikan. Semakin tinggi tingkat pendidikan yang pernah diraih, semakin tinggi kesadaran untuk menjaga kesehatan gigi dan mulut. ${ }^{6}$ Perubahan rongga mulut pada lansia antara lain mulut kering, warna pucat pada mukosa mulut, penipisan mukosa, atrisi, dan kehilangan gigi..$^{7-14}$ 
Dari sisi fisiologis, salah satu gangguan metabolisme hormonal adalah masa klimakterium, ${ }^{9,10}$ yang dikenal sebagai masa premenopause, menopause, dan pascamenopause. ${ }^{15}$ Masa premenopause dimulai dengan gangguan menstruasi dan masa pasca-menopause terjadi 3-5 tahun setelah masa menopause. ${ }^{14}$ Menopause adalah suatu periode berhentinya siklus menstruasi pada usia antara 45-55 tahun, dan terjadi penurunan hormon estrogen menjadi $1 / 10$ dari jumlah sebelumnya. ${ }^{11,15}$ Berkurangnya kadar estrogen karena menopause berkorelasi dengan kehilangan perlekatan jaringan periodontal, ${ }^{14}$ serta menjadi faktor terjadinya osteoporosis yang mempengaruhi resorpsi tulang alveolar dan hilangnya gigi. ${ }^{12,16-20} \mathrm{Hal}$ tersebut menyebabkan terganggunya fungsi pengunyahan pada lansia yang tak bergigi sehingga akan berpengaruh pada kesehatan umum karena adanya pemilihan makanan.,

Masalah yang sering terjadi pada bidang kesehatan gigi dan mulut adalah gangguan fungsi kunyah akibat perubahan gigi. ${ }^{3}$ Mastikasi adalah proses penghancuran makanan secara mekanik yang bertujuan membentuk bolus yang kecil sehingga dapat mempermudah proses penelanan. Komponen mastikasi terdiri dari gigi-geligi, sendi rahang, sistem saraf, dan otot-otot kunyah rongga mulut, dengan tahap-tahap yang terjadi yaitu tahap membuka mandibula, tahap menutup mandibula, dan tahap kontak gigi antagonis dengan gigi lain atau kontak gigi dengan makanan. ${ }^{21,22}$ Permukaan oklusal menjadi faktor penting, karena jumlah gigi berpengaruh terhadap pemecahan atau pelumatan makanan. ${ }^{21,23}$ Faktor usia mempengaruhi efektivitas mastikasi seperti, menurunnya pengurangan ukuran partikel serta durasi pengunyahan. ${ }^{24}$ Faktor-faktor lain yang mempengaruhi performa mastikasi yaitu kekuatan gigit, tingkat keparahan maloklusi, area kontak oklusal dan ukuran tubuh, dan fungsi motorik oral. ${ }^{25}$ Disfungsi lain berhubungan dengan jumlah saliva yang mempengaruhi proses mastikasi karena sulitnya pembentukan bolus sebelum menelan. ${ }^{26}$

Penurunan kemampuan mastikasi yang paling signifikan terdapat pada populasi lansia dengan keadaan tidak bergigi. ${ }^{27}$ Gangguan pada kemampuan mastikasi muncul pada individu yang memiliki kurang dari 20 atau kurang dari 10 pasang gigi dengan oklusi yang baik. ${ }^{7}$ Penelitian sebelumnya menunjukkan bahwa rerata jumlah kehilangan gigi lansia adalah $11,47 .{ }^{28}$ Kondisi tak bergigi mempengaruhi patologi otot pengunyahan dan mempengaruhi penurunan fungsi pengunyahan sesuai dengan faktor usia., ${ }^{5,20,25}$

Terjadi pula perubahan alveolar ridge yang berakibat perubahan dimensi vertikal dan perubahan status kesehatan gigi dan mulut. ${ }^{29}$ Gangguan lainnya seperti dari segi psikologis yang dialami perempuan menopause antara lain menjadi lebih emosional, sulit berpikir logis, gelisah, dan $\operatorname{mood}$ swing. ${ }^{9,11,12}$

Untuk mempertahankan fungsi mastikasi disarankan agar dilakukan pemeliharaan gigi posterior fungsional, karena prediksi kinerja mastikasi didasarkan pada kontak oklusal gigi. Dibutuhkan alat ukur yang akurat berdasarkan keadaan pasien, yaitu dengan cara mengetahui fungsi mastikasi sebagai parameter yang dapat dinilai secara subjektif. ${ }^{30}$ Rekam kontak oklusal dapat menggunakan indeks Eichner yang didasarkan pada kontak gigi asli rahang atas dan bawah di area molar bilateral dan premolar. ${ }^{31}$ Salah satu alat ukur kemampuan mastikasi pasien adalah dengan menggunakan kuesioner Hanin yang mengukur kemampuan mastikasi yang dibuat dengan baku emas indeks Eichner. ${ }^{30}$ Kuesioner Hanin mengukur kemampuan mastikasi secara subjektif dan digunakan dalam penelitian ini karena penelitian ini bertujuan menganalisis hubungan kehilangan gigi dengan kemampuan mastikasi perempuan pasca menopause secara subjektif.

\section{METODE}

Metode yang digunakan adalah studi analitik observasional secara potong lintang di Posbindu Lansia Pergeri Depok RW 02 di Jalan Mangga Raya No.88A Kelurahan Depok Jaya. Jumlah sampel 95 perempuan pasca menopause usia 47-84 tahun. Kondisi fisik sehat, berhenti menstruasi selama minimal setahun, tidak menderita diabetes atau osteoporosis, tidak mengkonsumsi obat steroid, minimal kehilangan satu gigi, dan bersedia menjadi subjek penelitian.

Subjek ditentukan dengan teknik consecutive sampling. Pada subjek yang memenuhi kriteria dilakukan pemeriksaan rongga mulut dan pengisian kuesioner dengan wawancara. Kemampuan mastikasi subjektif dinilai dengan kuesioner Hanin yang terdiri dari 8 pertanyaan dengan penilaian kuantitatif berupa skor, telah divalidasi, diuji, dan menunjukkan sensitivitas dan spesifisitas baik. ${ }^{30}$ Poin terkecil 0 dan poin terbesar 3 dengan nilai titik potong $\geq 12$. Skor $<12$ kemampuan kunyah buruk dan skor $\geq 12$ kemampuan kunyah baik. ${ }^{30}$

Kehilangan gigi diperiksa dengan menghitung banyaknya jumlah gigi yang hilang pada kedua rahang dengan tiga kategori, yaitu kategori 1 kehilangan $\geq 10$ gigi, kategori $2=6-10$ gigi, kategori $3 \leq 6$ gigi. ${ }^{30}$ Lama menopause responden dilakukan dengan cara pengisian kuesioner dan ditanyakan dengan dua kategori, yaitu kategori $1 \geq 5$ tahun, dan kategori $2 \leq 5$ tahun. ${ }^{13}$ Pendidikan subjek dikategorikan menjadi pendidikan dasar $=$ SD-SMP, menengah $=$ SMA/setara, tinggi = perguruan tinggi/setara. Pada subjek dilakukan pemeriksaan pemakaian gigi tiruan (GT) dan jenis GT yang digunakan, yaitu GTC, GTSL, dan gigi tiruan penuh (GTP). ${ }^{30}$

\section{HASIL}

Hampir 70\% subjek penelitian ini berusia lebih dari 60 tahun yang rata-rata mempunyai pendidikan menengah 
Tabel 1. Distribusi usia, tingkat pendidikan, lama menopause, kehilangan gigi dan pemakaian gigi tiruan kemampuan mastikasi subjek penelitian

\begin{tabular}{llll}
\hline Variabel & & Jumlah & $\%$ \\
\hline Usia & Lansia & 68 & 71 \\
& Bukan Lansia & 28 & 30 \\
Tingkat & Pendidikan Dasar & 37 & 39 \\
pendidikan & $\begin{array}{l}\text { Pendidikan Menengah } \\
\text { Pendidikan Tinggi }\end{array}$ & 44 & 46 \\
& & & 15 \\
Lama & >5 Tahun & 75 & 79 \\
menopause & $\leq 5$ Tahun & 20 & 21 \\
Pemakaian & Ya & 23 & 24 \\
gigi tiruan & Tidak & 72 & 76 \\
Kemampuan & Baik & 62 & 65 \\
mastikasi & Buruk & 33 & 35 \\
\hline
\end{tabular}

Tabel 2. Hubungan usia, tingkat pendidikan, lama menopause, dan pemakaian gigi tiruan dengan kemampuan mastikasi

\begin{tabular}{lllll}
\hline \multirow{2}{*}{ Variabel } & & \multicolumn{3}{c}{$\begin{array}{c}\text { Kemampuan Mastikasi } \\
\text { (n= 95) }\end{array}$} \\
\cline { 3 - 5 } & & $\begin{array}{c}\text { Baik } \\
(\mathbf{1 0 0 \%})\end{array}$ & $\begin{array}{c}\text { Buruk } \\
(\mathbf{1 0 0} \%)\end{array}$ & \multicolumn{1}{c}{} \\
\hline Usia & Lansia & $39(63 \%)$ & $28(85 \%)$ & $0,025^{*}$ \\
& Bukan Lansia & $23(37 \%)$ & $5(15 \%)$ & \\
Tingkat & Dasar & $23(37 \%)$ & $14(27 \%)$ & 0,849 \\
pendidikan & Tengah & $30(48 \%)$ & $14(27 \%)$ & \\
& Tinggi & $9(15 \%)$ & $24(46 \%)$ & \\
Lama & $>5$ Thn & $44(71 \%)$ & $31(94 \%)$ & $0,009^{*}$ \\
menopause & $\leq 5$ Thn & $18(29 \%)$ & $2(6 \%)$ & \\
Jumlah & $>10$ & $22(35 \%)$ & $22(67 \%)$ & $0,011^{*}$ \\
gigi hilang & $10-6$ & $19(31 \%)$ & $7(21 \%)$ & \\
& $<6$ & $21(34 \%)$ & $4(12 \%)$ & \\
\multirow{2}{*}{$\begin{array}{l}\text { Pemakaian } \\
\text { gigi tiruan }\end{array}$} & Ya & $14(23 \%)$ & $9(27 \%)$ & 0,611 \\
\hline
\end{tabular}

Keterangan: tanda $*=$ bermakna $(\mathrm{p}<0,05)$

dan hanya sedikit dari subjek dengan masa menopause kurang dari 5 tahun (Tabel 1). Lebih dari 75\% subjek penelitian tidak menggunakan gigi tiruan dan sekitar $65 \%$ subjek masih mempunyai kemampuan mastikasi yang baik (Tabel 1).

Untuk melihat hubungan yang bermakna antara usia, tingkat pendidikan, lama menopause, serta kehilangan gigi terhadap kemampuan mastikasi, dilakukan analisis bivariat dengan Chi Square dengan hasil pada Tabel 2. Terdapat hasil berupa faktor kehilangan gigi memiliki nilai kemaknaan $(p)$ sebesar 0,011, faktor usia dan lama menopause 0,025 dan 0,009 merupakan hubungan bermakna karena $(p<0,05)$. Tingkat pendidikan dan pemakaian GT mempunyai faktor peluang lebih dari $5 \%(p>0,05)$ maka hubungan kurang bermakna secara statistik dengan kemampuan mastikasi.

\section{PEMBAHASAN}

Dari hasil penelitian ini, besar proporsi kehilangan gigi tertinggi pada perempuan pasca menopause terdapat pada kategori lebih dari 10 gigi hilang. Sesuai penelitian terdahulu, seiring terjadinya pertambahan usia, rongga mulut akan mengalami perubahan jaringan lunak dan jaringan keras, antara lain meningkatnya karies gigi dan penyakit periodontal. Bila terus berlanjut tanpa perawatan maka dapat berakibat hilangnya gigi. ${ }^{20}$ Dari ketiga kategori jumlah gigi asli yang hilang, semakin banyak gigi yang hilang, semakin banyak persentase subjek yang memiliki kemampuan mastikasi yang buruk. Hasil data penelitian ini mendukung penelitian terdahulu yang membuktikan bahwa jumlah gigi akan mempengaruhi pemecahan makanan menjadi bolus dan area oklusal yang dibutuhkan untuk kemampuan mastikasi, semakin sedikit jumlah gigi posterior, sehingga semakin buruk kemampuan mastikasi. ${ }^{23,26}$ Hasil penelitian memperlihatkan bahwa subjek yang memiliki efisiensi mastikasi baik memiliki kontak antar gigi molar asli atau premolar asli pada rahang atas dan bawah serta jumlah gigi asli yang berfungsi sehingga restorasi dan hilangnya gigi posterior pada lansia mempengaruhi kinerja mastikasi. ${ }^{7,25,33}$

Didapatkan hasil pada subjek yang telah mengalami menopause selama lebih dari 5 tahun proporsi subjek dengan kemampuan mastikasi yang buruk lebih tinggi dibandingkan dengan yang memiliki kemampuan mastikasi baik. Secara fisiologis, pada perempuan pasca menopause terjadi perubahan metabolisme hormonal dan muskoloskeletal. ${ }^{10,15}$ Juga terjadi penurunan kadar estrogen pada masa menopause dihubungkan dengan peningkatan resorpsi tulang alveolar, kehilangan perlekatan jaringan periodontal, peningkatan keparahan penyakit periodontal dan kehilangan gigi. ${ }^{34,35}$ Lama menopause mempengaruhi penurunan densitas tulang yang mengakibatkan terjadinya kehilangan gigi sehingga terjadi penurunan kemampuan mastikasi.

Faktor usia juga menunjukkan korelasi bermakna terhadap kemampuan mastikasi. Usia mempengaruhi kemampuan mastikasi secara tidak langsung dengan terjadinya berbagai perubahan fisik maupun fisiologis yang mengakibatkan adanya penyakit periodontal serta kondisi menopause yang mempengaruhi gigi dan rongga mulut. Penurunan fungsi otot sendi temporomandibular serta suatu kondisi dalam tubuh yang mempengaruhi rongga mulut dapat mempengaruhi kualitas mastikasi. ${ }^{21}$ Penelitian sebelumnya mendapatkan adanya hubungan antara perubahan densitas tulang mandibula terhadap usia pada subjek perempuan menopause. ${ }^{18}$ Beberapa penelitian sebelumnya mendukung hasil dalam penelitian ini, bahwa faktor usia dapat mempengaruhi kemampuan mastikasi.

Tidak ditemukan hubungan penggunaan GT dengan kemampuan mastikasi dalam penelitian ini. Hal ini 
dapat disebabkan karena jenis dan kualitas GT yang digunakan. Berdasarkan data yang dikumpulkan, subjek lebih banyak menggunakan GTSL anterior untuk estetika dibandingkan untuk pengunyahan. Adanya penggantian gigi yang hilang dengan menggunakan GTSL tidak membuat kinerja mastikasi lebih baik daripada kinerja mastikasi yang terjadi pada rahang dengan jumlah gigi asli yang masih lengkap. ${ }^{4,5}$ Oleh karena itu diperlukan penelitian spesifik mengenai hubungan jenis GT dengan kemampuan mastikasi, karena penilaian untuk GTC berbeda dengan GTSL. Menurut indeks Eichner, gigi yang direstorasi dengan menggunakan GTC dianggap sama dengan gigi asli. $^{30,32,33}$

Dari penelitian ini tidak ditemukan korelasi bermakna antara kemampuan mastikasi dengan tingkat pendidikan. Hal ini berhubungan dengan kesadaran atas perawatan gigi mulut. Walaupun diketahui semakin tinggi tingkat pendidikan yang pernah diraih, semakin tinggi kesadaran untuk menjaga kesehatan gigi dan mulut ${ }^{6}$ namun ternyata hal tersebut tidak berlaku untuk perempuan lansia. Berbagai macam alasan mendasari hal ini, seperti tidak memprioritaskan kesehatan gigi, rasa takut, sulitnya mobilisasi, dan adanya anggapan bahwa terjadinya kehilangan gigi pada lansia adalah normal. ${ }^{28,36}$ Pentingnya hal ini diperlihatkan dalam penelitian terdahulu, bahwa untuk menjaga kesehatan gigi dan mulut agar tetap memiliki fungsi mastikasi dibutuhkan perilaku, kesadaran, dan motivasi diri yang baik. ${ }^{7}$

Faktor yang merupakan kekurangan penelitian ini antara lain proporsi sampel yang kurang berimbang untuk membuktikan adanya perbedaan bermakna, kelelahan pewawancara dalam menggali jawaban, dan kelelahan subjek penelitian dalam menjawab pertanyaan. Bias data yang mungkin terjadi adalah cara penilaian subjek mengenai pertanyaan kemampuan mengunyah, perbandingan lama waktu menghabiskan makanan dengan orang lain yang relatif dari tiap subjek. Hal ini dapat menjelaskan ditemukannya subjek yang memiliki kemampuan mastikasi baik dengan jumlah kehilangan gigi banyak. Pengembangan ilmu dan pelayanan di bidang Prostodonsia dapat dilakukan peningkatan edukasi dan kesadaran untuk para perempuan mengenai kesehatan gigi dan mulut. Diharapkan Prostodontis meningkatkan pelayanan yang berkaitan dengan GT serta memotivasi pemeliharaan kesehatan gigi. Disarankan untuk penelitian berikutnya menggunakan jumlah sampel lebih berimbang proporsinya dengan turut mempertimbangkan faktor sosio-demografik sebagai salah satu faktor risiko serta penelitian lebih spesifik mengenai korelasi antara jenis GT yang digunakan dengan kemampuan mastikasi. Untuk penelitian selanjutnya, perilaku subjek dalam menjaga kebersihan gigi dan mulut dengan kemampuan mastikasi dapat dijadikan variabel konfonding untuk memperjelas hubungan dengan kemampuan mastikasi.

\section{SIMPULAN}

Ada hubungan bermakna antara kehilangan gigi, usia, dan lama menopause dengan kemampuan mastikasi pada perempuan pasca menopause.

\section{DAFTAR PUSTAKA}

1. Khosama H, Lumempouw S, Lastri DN, Rachman IA, Prihartono J. Hubungan kadar serum hormon estrogen dengan memory performance pada wanita pasca menopause. Neurona. 2008;25:37-43. Indonesian.

2. Laporan Hasil Riset Kesehatan Dasar RISKESDAS Indonesia 2007. Jakarta: Departemen Kesehatan Republik Indonesia; 2008. Indonesian.

3. Mawi M. Proses menua sistem organ tubuh pada lanjut usia. Maj Ilmiah Ked Gigi. 2001;16:61. Indonesian.

4. Kotzer RD, Lawrence HP, Clovis JB, Matthews DC. Oral health related quality of life in an aging Canadian population. Health Qual Life Outcomes. 2012;10:50.

5. Amurwaningsih M, Nisaa' U, Darjono A. Analisis hubungan kualitas hidup yang berhubungan dengan kesehatan mulut (OHRQoL) dan status kecemasan dengan status nutrisi pada masyarakat. Maj Ilmiah Sultan Agung.[internet] 2010; 48. Available from: http://jurnal.unissula.ac.id/index. php/majalahilmiahsultanagung/article/view/25/21. Indonesian.

6. Bayraktar G, Kurtulus I, Kazancioglu R, Bayramgurler I, Cintan S, Bural C, et al. Effect of educational level on oral health in peritoneal and hemodialysis patients. Int J Dent. 2009;2009:159767.

7. Musacchio E, Perissinotto E, Binotto P, Sartori L, Silva-Netto F, Zambon S, et al. Tooth loss in the elderly and its association with nutritional status, socio-economic and lifestyle factors. Acta Odontol Scand. 2007;65:78-86.

8. Pudjirochani E. Cara penanganan penderita lanjut usia di bidang Prostodonsia. Dent J. 2002;35:3-36. Indonesian.

9. Ghani L. Seluk beluk menopause. Media Penelit dan Pengembang Kesehat. 2009;XIX:193-6. Indonesian.

10. Soemitro S. Kesehatan jaringan periodontal pada lanjut usia. JITEKGI. 2006;3:38-41. Indonesian.

11. Oktafiani D. Faktor-faktor yang mempengaruhi aktivitas seksual pada lanjut usia di Posyandu wilayah kerja Puskesmas Andalas Fakultas Kedokteran [dissertation]. Padang: Universitas Andalas; 2010. Indonesian.

12. Holm-Pedersen P, Loe H. Textbook of geriatric dentistry. Copenhagen: Munksgaard; 1996.

13. Bhardwaj A, Bhardwaj SV. Effect of menopause on women's periodontium. J Midlife Health. 2012; 3:5-9. 
14. Arina YMD. Kebutuhan perawatan periodontal wanita menopause. Maj Ilmiah Ked Gigi. 2006;21:101-3. Indonesian.

15. Polotsky HN, Polotsky AJ. Metabolic implications of menopause. Semin Reprod Med. 2010;28:42634.

16. Raisz LG. Pathogenesis of osteoporosis: concepts, conflicts and prospects. J Clin Invest. 2005;115:3318-25.

17. Lestari S, Boesro S, Sudhana W. Gambaran perilaku dan status kesehatan gigi dan mulut lansia di Puskesmas kecamatan Kemayoran Jakarta Pusat. Maj Ilmiah Ked Gigi. 2005;20:83-9. Indonesian.

18. Kusdhany ML, Iskandar HH, Rahardjo T. Faktorfaktor yang berhubungan dengan densitas tulang mandibula pada perempuan pascamenopause. J Dent Indones. 2004;11:8-12. Indonesian.

19. Anggraini W. Fitoestrogen sebagai alternatif alami terapi sulih hormon untuk pengobatan osteoporosis primer pada wanita pascamenopause. Maj Ilmiah Ked Gigi. 2008;23-5. Indonesian.

20. Ikebe K. Masticatory performance in older subjects with varying degrees of tooth loss. J Dent. 2012;40:71-6.

21. Gomes SG, Custodio W, Cury AA, Garcia RC. Effect of salivary flow rate on masticatory efficiency. Int J Prosthodont. 2009;22:168-72.

22. The World's Women 2010 Trends and Statistics. [internet]. In: Affairs DoEaS, editor. New York: United Nations; 2010. Available from: https:// unstats.un.org/unsd/demographic/products/ Worldswomen/wwVaw2010.htm

23. Bourdiol P, Mioche L. Correlations between functional and occlusal tooth-surface areas and food texture during natural chewing sequences in humans. Arch Oral Biol. 2000;45:691-9.

24. Woda A, Foster K, Mishellany A, Peyron MA. Adaptation of healthy mastication to factors pertaining to the individual or to the food. Physiol Behav. 2006;89:28-35.

25. Hatch JP, Shinkai RSA, Sakai S, Rugh JD, Paunovich ED. Determinants of masticatory performance in dentate adults. Arch Oral Biol. 2000;46:641-8.
26. Ikebe K, Matsuda K-i, Kagawa R, Enoki K, Yoshida M, Maeda Y, et al. Association of masticatory performance with age, gender, number of teeth, occlusal force and salivary flow in japanese older adults: is ageing a risk factor for masticatory dysfunction? Arch Oral Biol. 2011;56:991-6.

27. Weijenberg RAF, Scherder EJA, Lobbezoo F. Mastication for the mind-The relationship between mastication and cognition in ageing and dementia. J Neu Bio Rev. 2011;35:483-97.

28. Sundjaja Y, Kusdhany ML, Fardaniah S. Hubungan antara kehilangan gigi dan pemakaian gigi tiruan dengan kualitas hidup pra-lansia dan lansia perempuan [thesis]. Jakarta: Universitas Indonesia; Mei 2010. Indonesian.

29. Jubhari EH. Upaya untuk mengurangi preparasi gigi fung shell bridge. Dentofasial. 2007;6:9-27. Indonesian.

30. Hanin I, Kusdhany ML, Gita F. Pengaruh kemampuan mastikasi terhadap kualitas hidup wanita pra lanjut usia dan wanita lanjut usia di wilayah Bekasi, Indonesia [thesis]. Jakarta: Universitas Indonesia; 2012. Indonesian.

31. Yoshino K, Kikukawa I, Yoda Y, Watanabe H, Fukai K, Sugihara N, et al. Relationship between Eichner Index and number of present teeth. Bull Tokyo Dent Coll. 2012;53:37-40.

32. Gotfredsen K, Walls A. What dentition assures oral function. Clin Oral Impl Res. 2007;18:34-45.

33. Ikebe K, Matsuda K, Morii K, Furuya-Yoshinaka M, Nokubi T, Renner RP. Association of masticatory performance with age, posterior occlusal contacts, occlusal force, and salivary flow in older adults. Int J Prosthodont. 2006;19:475-81.

34. Friedlander AH. The physiology, medical management and oral implications of menopause. J Am Dent Assoc. 2002;133:73-81.

35. Arina YMD, Sari DS, Yuniar NH. Hubungan antara status jaringan periodontal wanita menopause dengan lama menopause. Spirulina. 2006;1:43-52. Indonesian.

36. Kiyak HA. Recent advance in a behavioral sciences in geriartric dentistry. Gerontology. 1988;7:27-36. 